\title{
ERRATUM
}

\section{A Vibrio cholerae autoinducer-receptor pair that controls biofilm formation}

Kai Papenfort, Justin E Silpe, Kelsey R Schramma, Jian-Ping Cong, Mohammad R Seyedsayamdost \& Bonnie L Bassler

Nat. Chem. Biol. 13, 551-557 (2017); published online 20 March 2017; corrected after print 4 April 2017

In the version of this article initially published, the compound structure immediately upstream of DPO in the biosynthetic scheme in Figure $4 \mathrm{e}$ was redrawn incorrectly during production. The structure was missing a methyl group. The error has been corrected in the HTML and PDF versions of the article.

\section{ERRATUM}

\section{Full antagonism of the estrogen receptor without a prototypical ligand side chain}

Sathish Srinivasan, Jerome C Nwachukwu, Nelson E Bruno, Venkatasubramanian Dharmarajan, Devrishi Goswami, Irida Kastrati, Scott Novick, Jason Nowak, Valerie Cavett, Hai-Bing Zhou, Nittaya Boonmuen, Yuechao Zhao, Jian Min, Jonna Frasor, Benita S Katzenellenbogen, Patrick R Griffin, John A Katzenellenbogen \& Kendall W Nettles

Nat. Chem. Biol. 13, 111-118 (2017); published online 21 November 2016; corrected after print 17 March 2017

In the version of this article initially published, some of the chemical compounds were incorrectly numbered as stereoisomers instead of racemates and some of the stereoisomers were marked with incorrect stereocenter configurations. In numerous instances throughout the main text and Online Methods, compounds $1-13$ were incorrectly called $1 R-13 R$ (6 instances of $13 R$ are correct and were left unchanged). In the legend for Figure $5: 1 S, 4 S, 11 S, 12 S, 13 S$ were incorrectly called $1 R, 4 R, 11 R, 12 R, 13 R$, respectively; in the left column of p.115: $1 S, 4 S, 11 S$ were incorrectly called $1 R, 4 R, 11 R$, respectively; and in the left column of p.116: $13 S$ was incorrectly called $13 R$. The errors have been corrected in the HTML and PDF versions of the article.

\section{CORRIGENDUM}

\section{Full antagonism of the estrogen receptor without a prototypical ligand side chain}

Sathish Srinivasan, Jerome C Nwachukwu, Nelson E Bruno, Venkatasubramanian Dharmarajan, Devrishi Goswami, Irida Kastrati, Scott Novick, Jason Nowak, Valerie Cavett, Hai-Bing Zhou, Nittaya Boonmuen, Yuechao Zhao, Jian Min, Jonna Frasor, Benita S Katzenellenbogen, Patrick R Griffin, John A Katzenellenbogen \& Kendall W Nettles

Nat. Chem. Biol. 13, 111-118 (2017); published online 21 November 2016; corrected after print 17 March 2017

In the version of this article initially published, Figure 1 was missing the ring designation letters, the substituent designation $\left(\mathrm{R}_{1} / \mathrm{R}_{2}\right)$ and the ring locant numbers for the compounds in panel a. The error has been corrected in the HTML and PDF versions of the article. 